\title{
Rare Cytogenetic Anomalies in Two Pediatric Patients with Acute Leukemia
}

\author{
Akut Lösemili Iki Pediatrik Hastada Nadir Görülen Sitogenetik Anomaliler
}

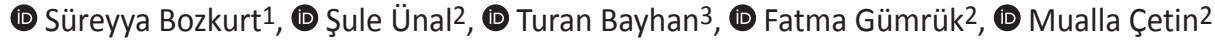 \\ 1/stinye University Faculty of Medicine, Department of Medical Biology, istanbul, Turkey \\ 2 Hacettepe University Faculty of Medicine, Department of Pediatric Hematology, Ankara, Turkey \\ ${ }^{3}$ Dr. Abdurrahman Yurtaslan Oncology Hospital, Clinic of Pediatric Oncology and Hematology, Ankara, Turkey
}

To the Editor,

Structural chromosomal abnormalities are frequently seen in both pediatric acute lymphoblastic leukemia (ALL) and acute myeloid leukemia (AML) cases $[1,2,3]$. Although some chromosomal abnormalities are common, other abnormalities are rarely seen $[4,5]$. In this study two relatively rare cytogenetic abnormalities are reported.

All procedures were performed in accordance with the Helsinki Declaration and approved by the local ethics committee (Approval No: G0 16/267-45).

\section{Case One}

CALLA+ pre-B-cell ALL was diagnosed in an 8-year-old-boy. The complete blood count (CBC) at diagnosis revealed hemoglobin of $5.5 \mathrm{~g} / \mathrm{dL}$, white blood cell (WBC) count of $2.8 \times 10^{9} / \mathrm{L}$, and platelet count of $301 \times 10^{9} / \mathrm{L}$. He had $\mathrm{t}(1 ; 4)(q 42 ; q 22)$ in all twenty metaphases as a sole abnormality (Figure 1). The ALLICBFM-2009 treatment protocol was started. Bone marrow examination on day 15 revealed remission. The patient was diagnosed in 2006. The last follow-up visit was in December 2019 and he is still alive.

\section{Case Two}

A girl of two and half months was diagnosed with the AML FAB-M5 phenotype. She had no comorbid disease and the diepoxybutane (DEB) test for Fanconi's anemia was negative. CBC results at diagnosis revealed hemoglobin of $10 \mathrm{~g} / \mathrm{dL}$, WBC count of $9.2 \times 10^{9} / \mathrm{L}$, and platelet count of $365 \times 10^{\circ} / \mathrm{L}$. The AML-BFM-2004 protocol was initiated. The karyotype of the patient was $46, X X, t(1 ; 11)(p 32 ; q 23)[19] / 46, X X[1]$. Bone marrow aspiration of the patient showed that she had entered the remission.

Herein, we report two rare translocations. $\mathrm{t}(1 ; 4)(q 42 ; q 22)$ was found in Case 1 with ALL and this anomaly has been reported in one case to date according to the database in which we searched [6]. The previous case was also a pediatric ALL patient, as in our case [7]. While we found $t(1 ; 4)(q 42 ; q 22)$ as a sole abnormality in all metaphases, the anomaly was found in a complex karyotype in the previously reported case. The hybrid gene formed as a consequence of this $t(1 ; 4)(q 42 ; q 22)$ and its function are not known. Our case is the second reported case with this anomaly and thus contributes to the literature.

In our second case, $\mathrm{t}(1 ; 11)(\mathrm{p} 32 ; \mathrm{q} 23)$ was found, which has been seen in a total of seven pediatric AML cases to date [6]. The ages of patients in whom this abnormality was previously detected were between 0 and 12 years, two of them being infants; our patient was 2.5 months old. When the FAB classification of the patients was examined for the previously reported cases, M0, M1, M4, and M5 were found. Hayashi et al. [8] reported this anomaly for the first time in a 7-year-old patient with AML $\mathrm{M} 1$ and they did not find this anomaly at diagnosis; instead, it was detected during the remission of the patient. In our case, $t(1 ; 11)(p 32 ; q 23)$ was present at the time of diagnosis of acute
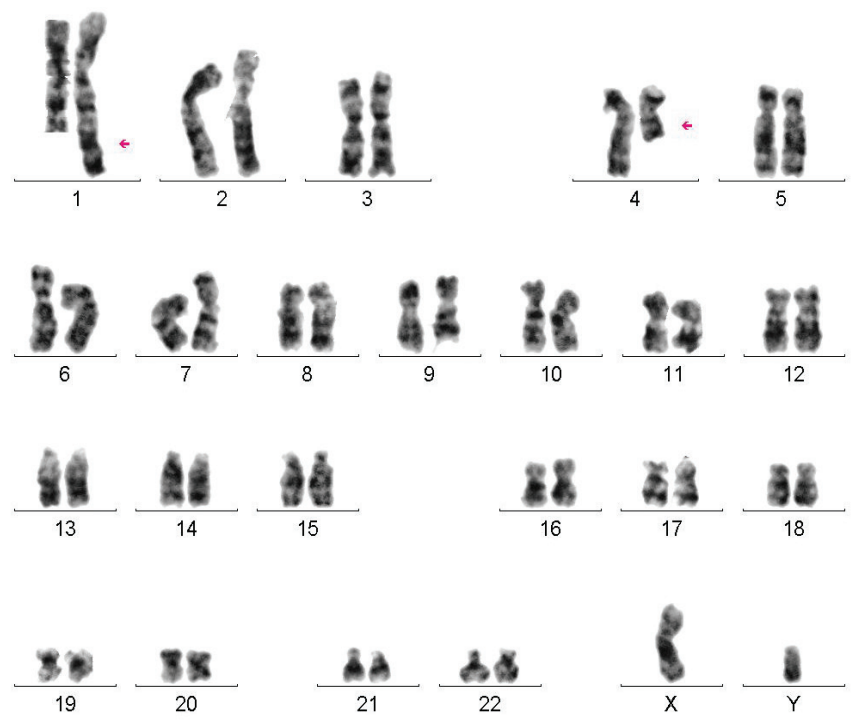

Figure 1 . Case 1 revealed $t(1 ; 4)(q 42 ; q 22)$ in all twenty metaphases as a sole abnormality. 
leukemia. The result of $t(1 ; 11)(p 32 ; q 23)$ is the $M L L-E P S 15$ fusion gene. The role of this fusion gene in the pathogenesis of $A M L$ is not known, but it has been suggested that the coiled-coil domains of EPS15 mediate oligomerization and activate MLL $[9,10,11]$.

The prognostic values of rare cytogenetic anomalies are unknown. The accumulation of knowledge about rare cytogenetic anomalies detected in childhood leukemia is expected to contribute to a better understanding of the pathogenesis of these diseases.

Key words: Acute myeloid leukemia, Rare cytogenetic anomalies, Karyotype

Anahtar Sözcükler: Akut myeloid lösemi, Nadir sitogenetik anomaliler, Karyotip

Informed Consent: Informed consent was received from the families of all patients.

\section{Authorship Contributions}

Concept: Ş.Ü., F.G., M.Ç.; Design: Ş.Ü., F.G., M.Ç.; Data Collection or Processing: S.B., T.B.; Analysis or Interpretation: Ş.Ü., S.B., T.B.; Literature Search: S.B.; Writing: S.B.

Conflict of Interest: The authors declare no conflict of interest.

\section{References}

1. Seth R, Singh A. Leukemias in children. Indian J Pediatr 2015;82:817-824.

2. Manola KN. Cytogenetics of pediatric acute myeloid leukemia. Eur J Haematol 2009;83:391-405.

3. Hunger SP, Mullighan CG. Redefining ALL classification: toward detecting high-risk ALL and implementing precision medicine. Blood 2015;125:39773987.
4. Iacobucci I, Mullighan CG. Genetic basis of acute lymphoblastic leukemia. J Clin Oncol 2017;35:975-983.

5. Harrison C. New genetics and diagnosis of childhood B-cell precursor acute lymphoblastic leukemia. Pediatric Rep 2011;3(Suppl 2):2-4.

6. Mitelman F, Johansson B, Mertens F. Mitelman Database of Chromosome Aberrations and Gene Fusions in Cancer. http://cgap.nci.nih.gov/ Chromosomes/Mitelman, 2017.

7. Behm FG, Raimondi SC, Schell MJ, Look AT, Rivera GK, Pui CH. Lack of CD45 antigen on blast cells in childhood acute lymphoblastic leukemia is associated with chromosomal hyperdiploidy and other favorable prognostic features. Blood 1992;79:1011-1016.

8. Hayashi Y, Raimondi SC, Behm FG, Santana VM, Kalwinsky DK, Pui CH, Mirro J Jr, William DL. Two karyotypically independent leukemic clones with the $\mathrm{t}(8 ; 21)$ and $11 \mathrm{q} 23$ translocation in acute myeloblastic leukemia at relapse. Blood 1989;73:1650-1655.

9. Rogaia D, Grignani F, Carbone R, Riganelli D, LoCoco F, Nakamura T, Croce CM, Di Fiore PP, Pelicci PG. The localization of the HRX/ALL1 protein to specific nuclear subdomains is altered by fusion with its eps 15 translocation partner. Cancer Res 1997;57:799-802.

10. Huret JL. $\mathrm{t}(1 ; 11)(\mathrm{p} 32 ; \mathrm{q} 23)$. Atlas Genet Cytogenet Oncol Haematol 2011;15:529-532.

11. Meyer C, Hofmann J, Burmeister $T$, Gröger D, Park TS, Emerenciano $M$, Pombo de Oliveira M, Renneville A, Villarese $P$, Macintyre $E$, Cavé $H$, Clappier E, Mass-Malo K, Zuna J, Trka J, De Braekeleer E, De Braekeleer M, Oh SH, Tsaur G, Fechina $L$, van der Velden VH, van Dongen JJ, Delabesse $E$, Binato $R$, Silva $M L$, Kustanovich A, Aleinikova O, Harris $M H$, Lund-Aho $T$, Juvonen V, Heidenreich O, Vormoor J, Choi WW, Jarosova M, Kolenova A, Bueno C, Menendez $\mathrm{P}$, Wehner $\mathrm{S}$, Eckert $\mathrm{C}$, Talmant $\mathrm{P}$, Tondeur $\mathrm{S}$, Lippert $\mathrm{E}_{\text {, Launay }}$ E, Henry C, Ballerini $P$, Lapillone $H$, Callanan MB, Cayuela JM, Herbaux $C$, Cazzaniga G, Kakadiya PM, Bohlander S, AhImann M, Choi JR, Gameiro P, Lee DS, Krauter J, Cornillet-Lefebvre P, Te Kronnie G, Schäfer BW, Kubetzko S, Alonso CN, zur Stadt U, Sutton R, Venn NC, Izraeli S, Trakhtenbrot L, Madsen HO, Archer P, Hancock J, Cerveira N, Teixeira MR, Lo Nigro L, Möricke A, Stanulla M, Schrappe M, Sedék L, Szczepanski T, Zwaan CM, Coenen EA, van den Heuvel-Eibrink MM, Strehl $S$, Dworzak M, Panzer-Grümayer $R$, Dingermann T, Klingebiel T, Marschalek R. The MLL recombinome of acute leukemias in 2013. Leukemia 2013;27:2165-2176.

๑Copyright 2020 by Turkish Society of Hematology

Turkish Journal of Hematology, Published by Galenos Publishing House

Address for Correspondence/Yazışma Adresi: Süreyya Bozkurt, M.D., İstinye University Faculty of Medicine,

Department of Medical Biology, İstanbul,Turkey

Phone : +90 8502836000

E-mail : sureyyabozkurt8@gmail.com ORCID: orcid.org/0000-0002-1765-9894
Received/Geliş tarihi: November 25, 2019

Accepted/Kabul tarihi: February 10, 2020

DOI: 10.4274/tjh.galenos.2020.2019.0425 